\title{
Consultation Length in Ambulatory Clinic of Belgrade Emergency Medical Service
}

\author{
Slavoljub R. Živanović ${ }^{1}$, Miloranka Đ. Petrov-Kiurski ${ }^{2}$ \\ ${ }^{1}$ City Institute for Emergency Medical Service, Belgrade, Serbia \\ ${ }^{2}$ Republic Health Insurance Fund, Zrenjanin Departement, Zrenjanin, Serbia
}

SUMMARY

The aim of the study was to analyze and compare consultation lengths in Emergency Medical Service (EMS) Belgrade ambulatory clinic which relate to patient age, gender, existing diagnoses and prescribed treatment (therapy or referral to anther healthcare institution).

We analyzed the data from the electronic database on consultation lengths from one EMS Belgrade Ambulatory Clinic. For patients who were further referred to another healthcare institution transfer, the waiting time was included in the total consultation time. We used the statistical package SPSS 11.0 for Windows for the statistical processing. Statistical significance was defined for the level of $p<0.05$.

The average consultation time was $21.07 \pm 13.44$ minutes. Usually, it lasted between 10 to 20 minutes. Consultations lasted longer in female patients (21.68 minutes), patients over 65 years of age (24.65 minutes), in patients with multiple diagnoses (26.1 and 27.28 minutes), as well as in patients where therapy was prescribed and administered in the ambulatory clinic (25.72 minutes), or in patients referred to other healthcare institutions. Statistically, the differences were highly significant $(p<0.01)$. When considering patients' diagnoses, longest consultations were in patients diagnosed with infectious diseases (average 30.88 minutes), followed by patients diagnosed with diseases of the circulatory system (27.86 minutes) and patients with diseases of the respiratory system (21.56 minutes). The differences were statistically significant $(\mathrm{p}<0.01)$.

Patients' age, gender, disease diagnosis and administered therapy affect the consultations time. Depending on the diagnosis, consultations last longer for infectious, cardiovascular and respiratory diseases.

Key words: consultation length, emergency medical services, primary health care

Corresponding author: 


\section{INTRODUCTION}

Consultation time encompasses all interactions between the patient and the doctor from the moment the patient enters the office to the moment when the patient leaves. Consultations have the following mandatory components: establishing the contact, data collection, objective examination, diagnosis, and therapeutic approach. The doctor fulfills all the tasks of the aforesaid components during the consultation (1).

There are various factors that influence the length of consultations. On the one hand, they concern patient's age, gender, type and number of health issues-multimorbidity, as well as sociodemograph-ic characteristics. On the other hand, they include physician's gender, length of service, existing workload, number of received patients, administration, level of exhaustion, presence of burnout syndrome).

According to Devugele's research, consultation length depends on the patient's age (2) but also on the nature of patient's health problems and conditions as well as patient's health needs (3). What is also important is that this health issue needs to be significant for both the doctor and the patient. A doctor's workload at the given time needs to be taken into consideration, whether therapy and check-up after the prescribed therapy is needed, if patient observation is required, and if transportation by ambulance to another healthcare institution for further diagnosis and treatment is needed.

The appropriate consultation length is extremely important for the quality of the provided healthcare services; however, not enough attention is given to this problem. Longer consultations may be associated with greater patient satisfaction (4). Back in 1991 Wilson found in his study that both patients and doctors had indicated that short consultation time resulted in poorer quality of the care provided, and that doctor's gender, length of service, training, number of received patients, as well as patient's newly presented health problem had direct influence on consultation length (5). Also, A. Levinson states in his paper that multiple lawsuits against doctors were related to shorter consultation times (6). In essence, patients were interested in the quality of health care they received regardless of the consultation length (7).

In the work of Natasha Elmore et al., they examined the connection between the length of consul- tations and patients' overall satisfaction with healthcare, i.e. being able to achieve good communication, trust and feelings of satisfaction with their healthcare providers for the healthcare services they received. The authors did not find that length of consultations influenced patients' experiences, stating further that patients can sometimes be satisfied with even a very short consultation for the services provided (15). Consultations also depend on patients' age. Older patients tend to have multiple conditions and can take longer to respond to questions, or sometimes even have hearing impairments, so it is to be expected that consultation times are longer than in younger patients.

Worldwide, the length of consultations has been extended over the past 30 years. In a study by Devugele, in six European countries the length of the consultation was significantly extended, i.e. from 8.65 minutes in 2007-08 to almost 10 minutes in 2013 - 14 (2), which was also confirmed by Hobbes in his work published in 2016 (8). Hobbes also states that how often consultations are performed during the year is important, including the age of patients. In the research of Nathan et al., no statistically significant difference was found in the length of consultations in relation to patient's age and gender (9). According to some studies, longer consultations achieve better clinical effectiveness and greater patient safety $(10,11)$.

The City Institute for Emergency Medical Services (CIEMS) belongs to the primary health care (PHC) system in Serbia and has an ambulatory outpatient clinic within its headquarters where patients can walk in 24 hours a day when having health problems. The work in the clinic is divided into two shifts: day shift and night shift, each lasting 12 hours and the clinic is staffed with either general medicine or emergency medicine specialists. This clinic is equipped with an oximeter, ECG machine, a set for cardiopulmonary resuscitation, and all the necessary therapeutic drugs for emergency care. The main difference between the outpatient clinic at CIEMS and the outpatient clinic of the community PHC center is that doctors in the community PHC centers likely know their patients, have their medical records, see the patients on a regular preventative basis and especially when they have health problems. In CIEMS, doctors usually see the patient for the first time and most often have no access to patient's medical records. The average number of examinations in one shift is $23-24$ and there is no 
time limit per consultation, nor a protocol on the maximum number of patients that can be seen and cared for during one shift. It is presumed that only urgent cases will be seen at the clinic, however, in most cases this is not the case as patients often do not want to wait to contact their family doctor at a later time (12).

In our country there are no articles on this topic. Although CIEMS belongs to primary health care, medical consultations are somewhat different than in community primary healthcare centers. In addition to physical examination, diagnostic testing and establishing clinical diagnosis, patients often receive ad hoc therapy which further requires monitoring of their conditions until symptoms are resolved and they can be discharged. For example, this includes checking patients' blood pressure, monitoring patients for allergic reactions after administration of therapy, performing additional diagnostic testing, referring patients to another healthcare institution and arranging for medical transportation, if needed. All of these steps further prolong the consultation time.

\section{AIMS}

The aim was to analyze and compare consultation lengths in EMS Belgrade ambulatory clinic as they relate to patient age, gender, existing diagnoses and prescribed treatment (therapy or referral to another healtcare institution).

\section{PATIENTS AND METHODS}

We analyzed the data from the electronic database on consultation lenghts from one EMS Belgrade ambulatory clinic as they relate to patient gender, age, diagnosis and treatment. The data was collected in the period from January 1 to December 31, 2016 from 2,197 patients in total, out which 2,137 patients had all the necessary information collected for the study. Due to the large scatter of study results, the data base was shortened by $5 \%$ of the longest and shortest results, so then the analysis included 1,923 patients. The physician who examined all the patients was a GP with a subspecialty in gerontology. When the patient comes into the clinic, an electronic medical record is created with automatically recorded start time. When the consultation is over, the patient receives a printed report with automatically recorded end time. For patients who need to be referred to another healthcare institution and who are waiting on medical transportation, the waiting time is also calculated in the consultation time. It is only at the time when the patient is leaving the CIEMS that the consultation report is being printed and end time is recorded. Consultation time is therefore the difference between the start and end time that is recorded on patient's report. For the purpose of statistical analysis and processing of consultation time lengths, there are seven intervals created: 1 .) up to 10 min; 2.) 10.01 to $15 \mathrm{~min}$; 3.) 15.01 to $20 \mathrm{~min}$; 4.) 20.01 to $30 \mathrm{~min} 5$.) 30.01 to $40 \mathrm{~min}$; 6.) $40.01 \mathrm{~d} 060 \mathrm{~min}$ and 7.) 60.01 to $75 \mathrm{~min}$. All patients were divided into two age groups. In the first group were those aged 65 and younger, and in the second group were those over the age of 65 . Data was presented as frequencies $(\%)$; the $\mathrm{X} 2$ test was used to measure the difference between the variables, and a one-factor ANOVA analysis was used to examine the correlation between the length of the consultation with the stated parameters. SPSS (Statistical Package for Social Sciences) 11.0 for Windows was used. Statistical significance was defined for the level of $p<0.05$.

\section{RESULTS}

The analysis included 1,923 patients of both genders (out of which $53.31 \%$ female) and 1,526 (or $79.36 \%$ ) patients were 65 years and younger. Upon examination, $43.96 \%$ of patients required some sort of therapy (oral medications, intravenous or intramuscular injections, IV drips, oxygen, bandaging) and $26.53 \%$ required further treatment and transportation to a tertiary healthcare institution. The most common health problem identified among the examined patients was related to the factors that affect the health condition, i.e. medical observation and monitoring due to suspicion of some diseases or conditions (code Z03 - according to ICD-10 classification), and then diseases of the circulatory system - most often arterial hypertension (Graph 1).

Consultation length ranged from 6.65 minutes up to 74.87 minutes. The average consultation time was $21.07 \pm 13.44$ minutes. In the majority of patients, the consultation lasted from 10 up to $20 \mathrm{~min}$ (Graph 2).

Consultation length was analyzed in relation to patients' gender, age, administered therapy and referral to another healthcare institution for further 


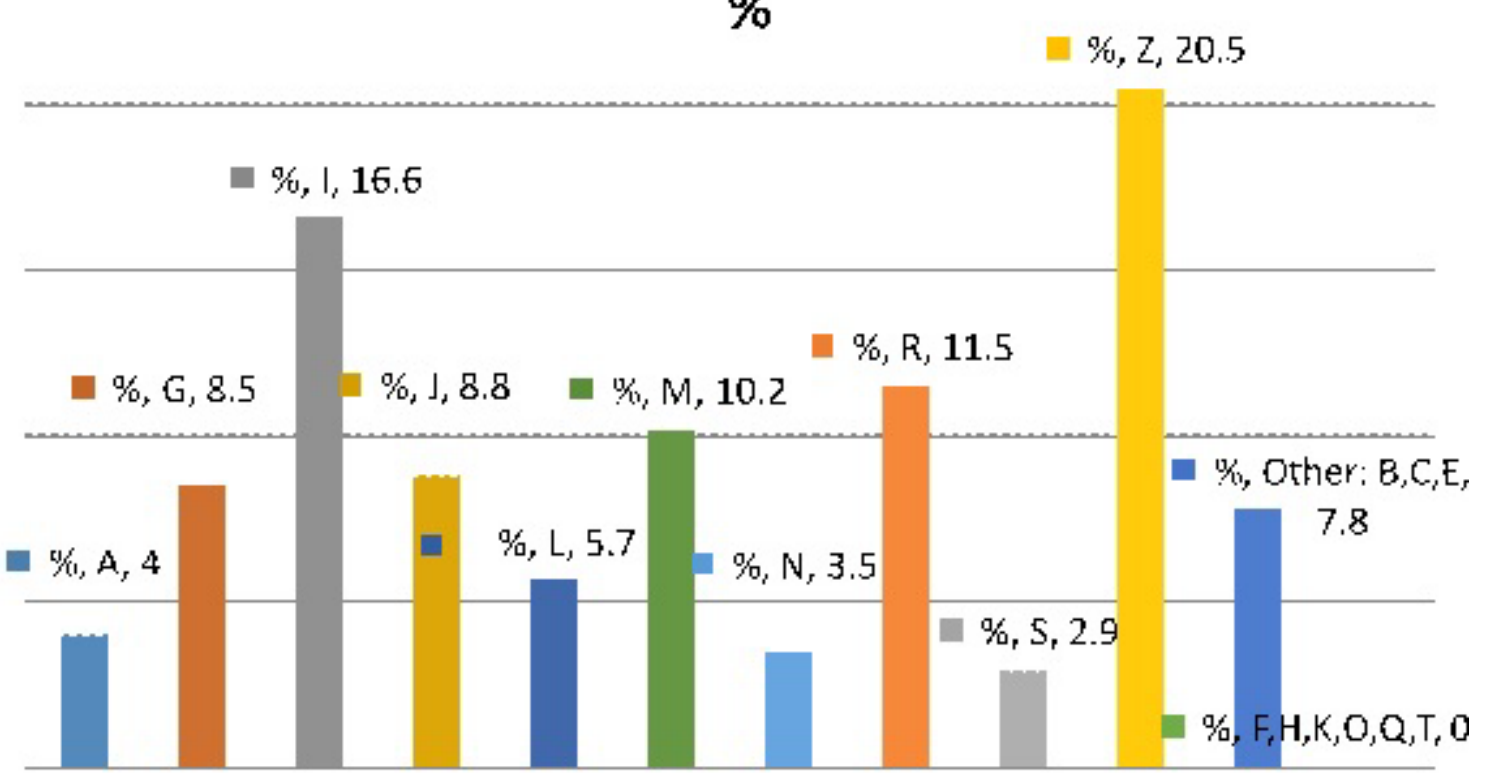

Graph 1. Prevalence of diseases and conditions in patients (according to ICD-10 classification)

\section{$\%$}

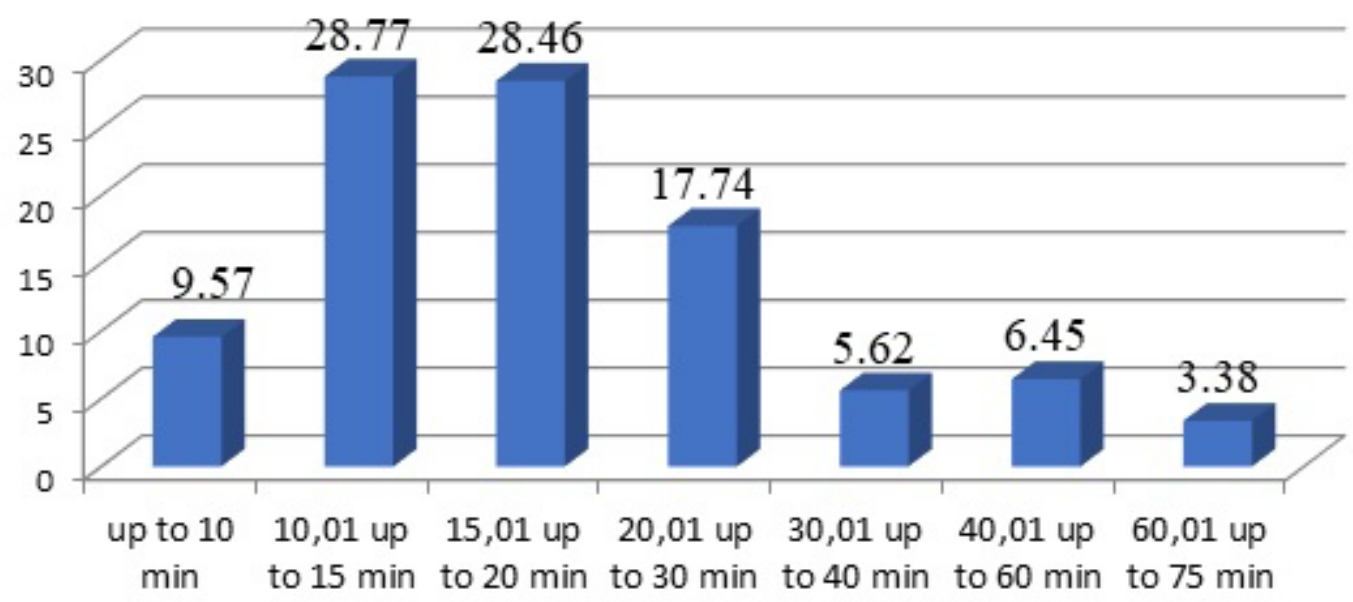

Graph 2. Distribution of patients in the EMS ambulatory clinic in relation to consultation length

Consultation length ranged from 6.65 minutes up to 74.87 minutes. The average consultation time was $21.07 \pm 13.44$ minutes. In the majority of patients, the consultation lasted from 10 up to $20 \mathrm{~min}$ (Graph 2).

treatment. Consultation length was also considered in relation to patients' present diagnosis and multimorbidity.

Consultations lasted longer in female patients (21.68 minutes), the ones older than 65 years (24.65 minutes), with multiple diagnoses (26.1 and 27.28 minutes), in patients for whom therapy was prescribed and administered in the EMS ambulatory clinic (25.72 minutes), or in patients requiring referral to another healthcare institution (Table 1 ). In each of these cases, the difference was statistically highly significant (Table 2).

In terms of diagnosis (Table 3), consultations lasted the longest for patients diagnosed with diseases from group A - infectious diseases (an average of $30.88 \mathrm{~min}$ ), followed by group I - diseases of the 
circulatory system (27.86 min) and group J - diseases of the respiratory system $(21.56 \mathrm{~min})$. In relation to the existing diagnoses, a statistically significant difference was found $(p=0.000)$. Consultations in patients with diagnosis from group $S$ - injury, poisoning and certain other consequences of external causes lasted the shortest on average, $14.04 \mathrm{~min}$. (Table 4). By using the Chi-square test, a statistically significant difference was found $(p=0.00)$.

By applying a one-factor analysis of variance (Anova) of different groups with subsequent tests, the statistical significance of the difference in the length of consultations between individual groups was obtained (Table 5). This statistical processing showed that the difference in the length of the consultations in patients with diseases from group A and from group I are highly statistically significant in relation to all other groups of diseases and conditions. Also, the difference in the length of consultations for diseases from group L (diseases of the skin and subcutaneous tissue), $\mathrm{M}$ (diseases of the musculoskeletal system and connective tissue) and $\mathrm{N}$ (diseases of the genitourinary system) is statistically significant only in relation to diagnoses from group $\mathrm{A}, \mathrm{I}$ and $\mathrm{S}$ (injuries, poisonings and consequences of external factors).

Table 1. Mean values of consultation time

(in minutes) in relation to the patients' characteristics

\begin{tabular}{c|c|c|c|l}
\hline \hline $\begin{array}{l}\text { Characteristics } \\
\text { of participants }\end{array}$ & $\mathrm{N}$ & $\%$ & $\begin{array}{l}\text { Mean } \\
\text { value }\end{array}$ & $\begin{array}{l}\text { Standard } \\
\text { deviation }\end{array}$ \\
\hline Gender & \multicolumn{5}{|c}{} \\
\hline male & 898 & 46.69 & 20.35 & 12.8 \\
\hline female & 1025 & 53.31 & 21.68 & 13.95 \\
\hline Age & \multicolumn{5}{|l}{} \\
\hline$\leq 65$ years & 1527 & 79.4 & 20.13 & 13.2 \\
\hline$>65$ years & 396 & 20.6 & 24.65 & 13.76 \\
\hline $\begin{array}{l}\text { Administered } \\
\text { therapy }\end{array}$ & \multicolumn{5}{|l}{} \\
\hline Yes & 845 & 43.96 & 25.72 & 17.19 \\
\hline No & 1078 & 56.04 & 17.04 & 7.75 \\
\hline $\begin{array}{l}\text { Referred to } \\
\text { another health } \\
\text { institution }\end{array}$ & \multicolumn{5}{|l}{} \\
\hline Yes & 510 & 26.53 & 23.59 & 14.01 \\
\hline No & 1413 & 73.47 & 20.15 & 13.11 \\
\hline $\begin{array}{l}\text { Number of } \\
\text { diagnoses }\end{array}$ & \multicolumn{5}{|l}{} \\
\hline 1 & 1709 & 88.87 & 20.43 & 13.02 \\
\hline 2 & 196 & 10.02 & 26.1 & 15.68 \\
\hline 3 & 18 & 1.11 & 27.28 & 14.74 \\
\hline \hline
\end{tabular}


Table 2. Distribution of patients by consultation length (in \%) in relation to the observed parameters

\begin{tabular}{l|c|c|c|c|c|c|c|c}
\hline \hline & \multicolumn{7}{|c|}{ Consultation length in min } & \\
\hline $\begin{array}{l}\text { Characteristics } \\
\text { of participants }\end{array}$ & Up to 10 & $10.01-15$ & $15.01-20$ & $20.01-30$ & $30.01-40$ & $40.01-60$ & $60.01-75$ & p-value \\
\hline Gender & & & & & & & & 0.014 \\
\hline Male & 11.1 & 31.3 & 26.9 & 16.2 & 6 & 5.4 & 3.1 & \\
\hline Female & 8.2 & 26.6 & 29.8 & 19.1 & 5.3 & 7.4 & 3.6 & \\
\hline Age & & & & & & & & 0.000 \\
\hline$\leq 65$ years & 11.1 & 31.5 & 28.6 & 14.5 & 5.2 & 5.6 & 3.4 & \\
\hline$>65$ years & 3.5 & 18.7 & 28 & 30.3 & 7.1 & 9.6 & 3.3 & \\
\hline $\begin{array}{l}\text { Administered } \\
\text { therapy }\end{array}$ & & & & & & & & 0.000 \\
\hline Yes & 8 & 19.6 & 20.7 & 21.1 & 9.7 & 13.4 & 7.5 & \\
\hline No & 10.8 & 35.9 & 34.5 & 15.1 & 2.4 & 1 & 0.2 & \\
\hline $\begin{array}{l}\text { Referred to another } \\
\text { health institution }\end{array}$ & & & & & & & & 0.000 \\
\hline Yes & 6.9 & 20.8 & 28 & 24.3 & 8.4 & 9.2 & 2.4 & \\
\hline No & 10.6 & 31.7 & 28.6 & 15.4 & 4.6 & 5.5 & 3.8 & \\
\hline \hline
\end{tabular}

* Statistical significance $\mathrm{p}<0.05$

Table 3. The average length of consultation (in minutes) in relation to diagnoses (according to ICD-10 th classification)

\begin{tabular}{c|c|c|c|c}
\hline \hline $\begin{array}{c}\text { Diagnosis by ICD } \\
-10^{\text {th }} \text { classification }\end{array}$ & $\begin{array}{c}\text { Number of } \\
\text { patients }\end{array}$ & $\%$ & $\begin{array}{c}\text { Mean } \\
\text { value }\end{array}$ & $\begin{array}{c}\text { Standard } \\
\text { deviation }\end{array}$ \\
\hline $\mathrm{A}$ & 77 & 4 & 30.88 & 21.55 \\
\hline $\mathrm{G}$ & 164 & 8.5 & 20.63 & 11.86 \\
\hline $\mathrm{I}$ & 319 & 16.6 & 27.86 & 17.81 \\
\hline $\mathrm{J}$ & 168 & 8.8 & 21.56 & 13.68 \\
\hline $\mathrm{L}$ & 110 & 5.7 & 20.62 & 14.93 \\
\hline $\mathrm{M}$ & 197 & 10.2 & 17.19 & 7.91 \\
\hline $\mathrm{N}$ & 67 & 3.5 & 18.87 & 8.46 \\
\hline $\mathrm{R}$ & 221 & 11.5 & 20.93 & 11.98 \\
\hline $\mathrm{S}$ & 56 & 2.9 & 14.04 & 9.34 \\
\hline $\mathrm{Z}$ & 394 & 20.5 & 17.5 & 7.36 \\
\hline Other: & & & & \\
\hline B,C,E,F,H,K,O,Q,T & 150 & 7.8 & 20.16 & 12.85 \\
\hline \hline
\end{tabular}


Table 4. Distribution of patients by consultation length (in \%) in relation to diagnoses (according to ICD-10 th classification)

\begin{tabular}{c|c|c|c|c|c|c|c}
\hline \hline \multirow{2}{*}{$\begin{array}{c}\text { Diagnosis by ICD } \\
10^{\text {th }} \text { classification }\end{array}$} & \multicolumn{7}{|c}{ Length of consultation in min } \\
\cline { 2 - 8 } & Up to 10 & $10.01-15$ & $15.01-20$ & $20.01-30$ & $30.01-40$ & $40.01-60$ & $60.01-75$ \\
\hline $\mathrm{A}$ & 2.6 & 13 & 15.6 & 7.8 & 10.4 & 31.2 & 19.5 \\
\hline $\mathrm{G}$ & 12.3 & 25.2 & 28.9 & 22.1 & 6.7 & 3.1 & 1.8 \\
\hline $\mathrm{I}$ & 1.3 & 15.4 & 26.7 & 23.3 & 10.7 & 12.6 & 10.1 \\
\hline $\mathrm{J}$ & 10.7 & 30.4 & 22.6 & 18.5 & 8.9 & 7.1 & 1.8 \\
\hline $\mathrm{L}$ & 20 & 32.7 & 19.1 & 12.7 & 3.6 & 10 & 1.8 \\
\hline $\mathrm{M}$ & 9.2 & 38.3 & 32.1 & 14.8 & 2 & 2 & 1.5 \\
\hline $\mathrm{N}$ & 6 & 34.3 & 32.8 & 20.9 & 4.5 & 1.5 & 0 \\
\hline $\mathrm{R}$ & 4.1 & 32.6 & 31.7 & 20.8 & 3.6 & 5.9 & 1.4 \\
\hline $\mathrm{S}$ & 50 & 28.6 & 8.9 & 10.7 & 0 & 1.8 & 0 \\
\hline $\mathrm{Z}$ & 9.7 & 33.6 & 37.9 & 15.3 & 2.3 & 1 & 0.3 \\
\hline Other: & 13.3 & 31.3 & 22.7 & 16.7 & 8 & 6 & 2 \\
\hline \hline
\end{tabular}

Statistical significance $\mathrm{p}<0.05$

Table 5. Differences in length of consultation with respect to diagnoses (according to ICD-10 th classification)

\begin{tabular}{|c|c|c|c|c|c|c|c|c|c|c|c|c|c|c|}
\hline \multicolumn{2}{|c|}{$\begin{array}{l}\text { Comparison } \\
\text { of diagnoses }\end{array}$} & \multirow{2}{*}{\begin{tabular}{|c|}
$\mathrm{p}$-value \\
0 \\
\end{tabular}} & \multicolumn{2}{|c|}{$\begin{array}{l}\text { Comparison } \\
\text { of diagnoses }\end{array}$} & \multirow{2}{*}{\begin{tabular}{|c|}
$\mathrm{p}$-value \\
0 \\
\end{tabular}} & \multicolumn{2}{|c|}{$\begin{array}{l}\text { Comparison } \\
\text { of diagnoses } \\
\end{array}$} & \multirow{2}{*}{$\begin{array}{c}\mathrm{p} \text {-value } \\
0 \\
\end{array}$} & \multicolumn{2}{|c|}{$\begin{array}{l}\text { Comparison } \\
\text { of diagnoses }\end{array}$} & \multirow{2}{*}{$\frac{\mathrm{p} \text {-value }}{0}$} & \multicolumn{2}{|c|}{$\begin{array}{l}\text { Comparison } \\
\text { Of diagnoses }\end{array}$} & \multirow{2}{*}{\begin{tabular}{|c}
$\mathrm{p}$-value \\
0
\end{tabular}} \\
\hline $\mathrm{A}$ & $\mathrm{G}$ & & \multirow[t]{10}{*}{$G$} & $\mathrm{~A}$ & & $\mathrm{I}$ & $\mathrm{A}$ & & \multirow[t]{10}{*}{$\mathrm{J}$} & $\mathrm{A}$ & & \multirow[t]{10}{*}{$\mathrm{L}$} & $\mathrm{A}$ & \\
\hline & $\mathrm{I}$ & 0 & & $\mathrm{I}$ & 0 & & $G$ & 0 & & $G$ & 1 & & $G$ & 0.993 \\
\hline & $\mathrm{J}$ & 0 & & $\mathrm{~J}$ & 1 & & $\mathrm{~J}$ & 0 & & $\mathrm{I}$ & 0 & & $\mathrm{I}$ & 0 \\
\hline & $\mathrm{L}$ & 0 & & $\mathrm{~L}$ & 0.993 & & $\mathrm{~L}$ & 0 & & $\mathrm{~L}$ & 0.824 & & $\mathrm{~J}$ & 0.824 \\
\hline & $\mathrm{M}$ & 0 & & $\mathrm{M}$ & 0.682 & & $\mathrm{M}$ & 0 & & $\mathrm{M}$ & 0.193 & & $\mathrm{M}$ & 1 \\
\hline & $\mathrm{N}$ & 0 & & $\mathrm{~N}$ & 1 & & $\mathrm{~N}$ & 0 & & $\mathrm{~N}$ & 0.972 & & $\mathrm{~N}$ & 1 \\
\hline & $\mathrm{R}$ & 0 & & $\mathrm{R}$ & 1 & & $\mathrm{R}$ & 0 & & $\mathrm{R}$ & 1 & & $\mathrm{R}$ & 0.865 \\
\hline & $S$ & 0 & & $S$ & 0 & & $S$ & 0 & & $S$ & 0 & & $S$ & 0.001 \\
\hline & $\mathrm{Z}$ & 0 & & $\mathrm{Z}$ & 0.306 & & $\mathrm{Z}$ & 0 & & $\mathrm{Z}$ & 0.03 & & $\mathrm{Z}$ & 0.998 \\
\hline & Other* & 0 & & $\begin{array}{c}\text { Other } \\
*\end{array}$ & 1 & & Other* & 0 & & Other* & 0.999 & & $\begin{array}{l}\text { Oth } \\
\text { er* }\end{array}$ & 0.997 \\
\hline \multicolumn{2}{|c|}{$\begin{array}{l}\text { Comparison } \\
\text { of diagnoses }\end{array}$} & p-value & \multicolumn{2}{|c|}{$\begin{array}{l}\text { Comparison } \\
\text { of diagnoses } \\
\end{array}$} & $\mathrm{p}$-value & \multicolumn{2}{|c|}{\begin{tabular}{|l|} 
Comparison \\
of diagnoses
\end{tabular}} & $\mathrm{p}$-value & \multicolumn{2}{|c|}{$\begin{array}{l}\text { Comparison } \\
\text { of diagnoses }\end{array}$} & $\mathrm{p}$-value & \multicolumn{2}{|c|}{$\begin{array}{l}\text { Comparison } \\
\text { of diagnoses }\end{array}$} & $\mathrm{p}$-value \\
\hline \multirow[t]{10}{*}{$\mathrm{M}$} & $\mathrm{A}$ & 0 & \multirow[t]{10}{*}{$\mathrm{N}$} & $\mathrm{A}$ & 0 & \multirow[t]{10}{*}{$\mathrm{R}$} & $\mathrm{A}$ & 0 & \multirow[t]{10}{*}{$S$} & $\mathrm{~A}$ & 0 & \multirow[t]{9}{*}{$\mathrm{Z}$} & $\mathrm{A}$ & 0 \\
\hline & $G$ & 0.682 & & $G$ & 1 & & $G$ & 1 & & $G$ & 0 & & $G$ & 0.306 \\
\hline & I & 0 & & I & 0 & & I & 0 & & I & 0 & & $\mathrm{I}$ & 0 \\
\hline & $\mathrm{J}$ & 0.193 & & $\mathrm{~J}$ & 0.972 & & $\mathrm{~J}$ & 1 & & $\mathrm{~J}$ & 0 & & $\mathrm{~J}$ & 0.03 \\
\hline & $\mathrm{L}$ & 1 & & $\mathrm{~L}$ & 1 & & $\mathrm{~L}$ & 0.865 & & $\mathrm{~L}$ & 0.001 & & $\mathrm{~L}$ & 0.998 \\
\hline & $\mathrm{N}$ & 1 & & $\mathrm{M}$ & 1 & & $\mathrm{M}$ & 0.196 & & $\mathrm{M}$ & 0.001 & & $\mathrm{M}$ & 1 \\
\hline & $\mathrm{R}$ & 0.196 & & $\mathrm{R}$ & 0.984 & & $\mathrm{~N}$ & 0.984 & & $\mathrm{~N}$ & 0.002 & & $\mathrm{~N}$ & 0.997 \\
\hline & $S$ & 0.001 & & $\mathrm{~S}$ & 0.002 & & $S$ & 0 & & $\mathrm{R}$ & 0 & & $\mathrm{R}$ & 0.023 \\
\hline & $Z$ & 1 & & $\mathrm{Z}$ & 0.997 & & $\mathrm{Z}$ & 0.023 & & $Z$ & 0.001 & & $S$ & 0.001 \\
\hline & Other* & 0.789 & & Other* & 1 & & Other* & 1 & & Other* & 0 & & $\begin{array}{l}\text { Oth } \\
\text { er* }\end{array}$ & 1 \\
\hline
\end{tabular}

*Other diagnoses are: B, C, E, F, H, K, O, Q, T 


\section{DISCUSSION}

The examined cohort consisted of 1,923 patients with approximately the same representation by gender and mostly consisting of patients up to 65 years of age. Patients over 65 had longer consultation times and $25.53 \%$ of them were referred to another healthcare institution for further testing and treatment. The largest number of patients had diagnoses from groups I, $\mathrm{R}$ and $\mathrm{Z}$ as per the International Classification of Diseases (ICD). Average consultation time was $21.07 \pm 13.44$ minutes, the minimum time was about seven minutes and maximum time around 75 minutes. The largest number of patients had one diagnosis and the maximum number of diagnoses per patient was three. Duration of consultation time increased by the number of diagnoses per patient. If patient was given ad hoc treatment, which further increased the consultation time. The largest number of patients with long consultation times were from group A as per the ICD.

The length of the consultation is influenced by patient-related as well as physician-related factors. Studies have generally analyzed the length of consultations as they are patient-related factors, but in the work of Peter K. Orton and Denise Pereira Gray, the length of consultation was compared to physician-related factors (3). In our work, we analyzed the length of consultations which refer to patient-related factors, since all examinations were performed by one physician in the CIEMS Belgrade outpatient clinic. When analyzing consultation length in the examined cohort, it was found that the consultations lasted $21.07 \mathrm{~min}$ on average, and for the largest number of patients the consultation lasted from 10 to 20 minutes. Duration of consultation times varies per country. In Andersson's and Mattsson's 1989 study published in Sweden, consultations lasted from 14-28 minutes and the average time was 21 minutes, which corresponds to our result (14). In a review paper, Wilson reports that the average consultation time in the USA is 10 minutes and $34.0 \%$ of those consultations last less than 5 minutes, $15.2 \%$ last more than 10 minutes, while in the United Kingdom consultations (49.5\%) last less than 5 minutes, and $7.9 \%$ last more than $10 \mathrm{~min}$. In a study by Kabey et al in Japan, the average duration of consultations in a diabetes practice was $10.1 \mathrm{~min}$ utes (15). The consultations usually last 12 minutes in New Zealand, 15 min in Canada and $21 \mathrm{~min}$ in Sweden (4). This means that both in the USA and the
UK almost $50 \%$ of consultations last between 5 and 10 minutes, and in the UK this is the case for over $40 \%$ of consultations.

As per our research, $75 \%$ of consultations last 10-30 minutes, with a peak value of 10-15 minutes for almost $29 \%$ of them. Dugdale in his paper reports that doctor's visits last 5-8 minutes in the UK, and 10 -20 minutes or more in Sweden and USA, according to 1994 data. The same author in the study from 1999 states that a patient consultation with a general practitioner in the United States lasted 20 minutes on average, and 26 minutes with an internist, and that shorter visits resulted in patients receiving several prescriptions (11). In our research, consultation time varies from 6.65 to 74.87 minutes and there are no prescribed medications other than the administered treatment because patients are advised to see their own family doctors in follow-up. When analyzed consultation times in six European countries from 2002, Deveugele et al. advise that consultations last 10.7 minutes $(7.6-15.6 \mathrm{~min})$ on average, with the longest consultation times in Belgium and Switzerland. They further state that consultations in urban areas last longer than in rural ones, with female patients having consultations 1 minute longer than male patients, however, the difference in gender and age is not statistically significant) (2). Our study was done in an urban environment, and this type of research has not been carried out in our country yet, so we cannot compare it with any other study. In 2012, Silverman and Kinnersley concluded that the consultation in the UK lasts 10 minutes, and that in longer consultations the physician has more opportunities to recognize even more complex psychosocial problems in patients, is able to better assess the problem of comorbidities and experiences less stress (6). Approximately the same consultation times were cited by Pankevich V. in his work in 2014 (3), and Hobs also concludes that consultation lengths approach the time of 10 minutes (10). In our research, consultations last 21 minutes on average (ranging from 6.65 to $74.87 \mathrm{~min}$ ). Most patients in EMS Belgrade outpatient clinic cannot be looked after in 10 minutes in total, as during the patient's stay in our clinic, they are often treated and counselled both before and after administration of therapy, and are also often waiting for transfer to a tertiary healthcare institution. Beccy B. (13) also says that it is difficult to assess the needs of patients with complex problems in only 10 minutes. Silverman J. and Kinnersley P. challenge the acceptability of a 10- 
minute consultation in the introduction of their study by stating that if a general practitioner needs to complete all the necessary elements of a consultation within 10 minutes only, there is a risk that some patients may receive an inadequately short consultation because the physician is trying to achieve the prescribed time (6). In our research, there is no prescribed length of consultation time, although in situations when facing very heavy workloads, staff feel the pressure to shorten the consultations. When it comes to emergency conditions for patients who need few check-ups or advice after administration of therapy, consultation times can hardly be any shorter.

When talking about consultation lengths, patients in general medicine are not necessarily as satisfied with the length of consultation as they are with the content and quality (16). Patients also seek explanations on what is going on with them, whether they are having an emergency condition that requires immediate attention or they need reassurance due to fears they may have in relation to their conditions (12). Patients with whom physicians spend more time in consultation are more likely to present important data and elements for adequate care (4). In the study of Andersson S - O, Mattsson B. it was reported that consultations lasted 21 minutes on average with great variations in consultation times among physicians and consultations with elderly patients lasted longer (14). In our study, consultation lengths are based on data from one physician only (out of five who work in the outpatient clinic) and the average time is 21 minutes. Older patients are seen as having more diseases on average, they use more medications, with slower response times, possibly with cognitive impairments, so consultations with older people on average last longer. Nathan et al. in Israel found that there is no difference in consultation length with respect to patient's age, they are even the shortest for people between 90 and 100 years of age and the longest in the 20-30 year olds with an average consultation time that does not exceed 8 minutes and with no gender difference (17). In our study, consultations in older people lasted longer by about 4.52 minutes on average and statistically there was a highly significant difference. Elmore et al. found that the consultations last anywhere between 2 to 28 minutes, most often 4-10 minutes (9), which is a lot shorter than in our research. When comparing consultation lengths in younger and older population groups, Brouns SHA et al. found that due to multiple tests and consultations with other specialists the median treatment time for the elderly was 158 minutes versus $130 \mathrm{~min}$ in younger patients (18). In a study by Deveugele M et al. in which they have analysed consultation times in six European countries, they found that female, elderly and patients with multiple health problems had longer consultations (2). Van den Bussche H. et al in their research say that 3.5 million elderly people in Germany who often suffer from psychiatric and psychosomatic symptoms and have multimorbidities often visit their GPs and their consultations last longer (19). In the patients covered in our study, consultations lasted longer if patients who had multiple diseases: for patients with two diagnosed illnesses consultations lasted 6.33 minutes longer, and for patients with three diagnosed illnesses consultations lasted 6.85 minutes longer than in patients with one diagnosed illness. As far as it concerns patients' age and gender, it is stated in the paper by Lemon TI et al. that six out of seven studies have shown that consultation times are increasing with patient's age, and five out of seven studies have shown that longer consultation times occur with female patients, which corresponds with our study (16). In our study, the average length of consultation in female patients is 1.33 minutes longer than in male patients. Parker BT and Marco C argue that consultation length has no significant connection with the patient's gender and age (19).

In our research, the longest consultations were with patients diagnosed with diseases from group A - infectious diseases, and then from group I - diseases of the circulatory system and group J - diseases of the respiratory system. Consultations with patients from group $\mathrm{S}$ diagnoses - injuries, poisoning and the consequences of external factors, lasted on average the shortest. Nathan TA et al. in their paper report that longest consultation times were in patients with multiple chronic illnesses, especially if they had chronic heart failure, chronic obstructive pulmonary disease and hypertension (17). Upon systematic review of literature Hutton C and Gunn J conclude that consultations in patients with diagnoses of a psychological problem last longer than those in whom psychological disorders have not been diagnosed (20). In our research, we obtained the same results. In the work of Jin G et al., it is stated that consultations are performed most frequently for medication prescriptions in $80 \%$ of cases, then for exhibited symptoms, check-ups, counselling, etc. 
and in $17.7 \%$ of cases patients seeked clarification from physicians about the symptoms they were feeling (21). In our research, there is usually no prescribing of medications and no scheduled check-ups, but patients often come to us due to health problems they are experiencing in search of diagnosis and counselling. As Pankevich V says in his study, their patients and their presented complaints were not homogeneous, and therefore their consultations varied so much within the same group (3). In our patients, consultations ranged from less than 10 minutes to over 70 minutes.

Andersson S.O. and Mattsson B. reported that the physician-related factors are the most important for the length of consultation (14). The more experienced a physician, the shorter the consultation times. Emotional exhaustion in general practitioners of female gender shortens consultation times, and in male physicians it extends them (22). Physicianrelated factors contributing to longer consultation times, i.e. physician's age, gender and level of training, are documented in eight studies (20).

\section{CONCLUSION}

The average consultation time was 21 minutes. In the majority of patients, the consultation lasted from 10 to 20 minutes. Consultations lasted longer in female patients, in patients over 65 years of age no matter what gender they were, in patients with multiple diagnoses, or in patients who had been given therapy or were referred to a tertiary healthcare institution. In all of these cases, the difference was statistically highly significant. In terms of diagnoses, longest consultations were in patients with diagnoses of infectious diseases, then diseases of the circulatory system and respiratory diseases. It is our opinion that consultation times achieved in the EMS Belgrade ambulatory clinic are acceptable for satisfactory treatment of patients.

\section{Abbreviations}

CIEMS - City Institute for Emergency Medical Services; UK - United Kingdom; ICD 10 ${ }^{\text {th }}$ - International Classification of Diseases, $10^{\text {th }}$ revision.

\section{References}

1. Pendleton D. The Consultation: An Approach to Learning and Teaching. Oxford Oxfordshire; New York: Oxford University Press; 1984. 130 p.

2. Deveugele M, Derese A, van den Brink-Muinen Aet al. Consultation length in general practice: cross sectional study in six European countries. BMJ. 2002;325(7362):472.

https://doi.org/10.1136/bmj.325.7362.472

3. Pankevich V. Patient demographics as a predictive tool of consultation duration. London J Prim Care (Abingdon). 2014;6(4):79-83. https://doi.org/10.1080/17571472.2014.11493421
4. Wilson A. Consultation length in general practice: a review. Br J Gen Pract. 1991;41(344):119-22.

5. Miyakoshi N, Kudo D, Matsuyama Y, et al. Impact of Consultation Length on Satisfaction in Patients with Chronic Low Back Pain: A Nationwide Multicenter Study in Japan. Spine Surg Relat Res. 2020;4(3):208-15. https://doi.org/10.22603/ssrr.2019-0111

6. Silverman J, Kinnersley P. Calling time on the 10minute consultation. $\mathrm{Br}$ J Gen Pract. 2012;62(596):118-9. https://doi.org/10.3399/bjgp12X625102 
7. Levinson W, Roter DL, Mullooly JP, et al. Physician-patient communication. The relationship with malpractice claims among primary care physicians and surgeons. JAMA. 1997;277(7):553-9.

https://doi.org/10.1001/jama.1997.03540310051034

8. van den Bussche H, Kaduszkiewicz H, Schäfer I, et al. Overutilization of ambulatory medical care in the elderly German population?--An empirical study based on national insurance claims data and a review of foreign studies. BMC Health Serv Res. 2016;16:129.

https://doi.org/10.1186/s12913-016-1357-y

9. Elmore N, Burt J, Abel G, et al. Investigating the relationship between consultation length and patient experience: a cross-sectional study in primary care. Br J Gen Pract. 2016;66(653):e896-903. https://doi.org/10.3399/bjgp16X687733

10. Hobbs FDR, Bankhead C, Mukhtar T, et al. Clinical workload in UK primary care: a retrospective analysis of 100 million consultations in England, 2007-14. Lancet. 2016 Jun 4;387(10035):2323-30. https://doi.org/10.1016/S0140-6736(16)00620-6

11. Dugdale DC, Epstein R, Pantilat SZ. Time and the patient-physician relationship. J Gen Intern Med. 1999;14 Suppl 1:S34-40.

https://doi.org/10.1046/j.1525-1497.1999.00263.x

12. Plazinić ĐM, Živanović SR. Symptoms that required ECG diagnostics in the ambulatory unit of the city institute for urgent medical care Belgrade. ABC - časopis urgentne medicine [Internet]. 2017 [cited 2020 Jun 3];17(3):66-70. https://doi.org/10.5937/abc1703066P

13. Baird B, Charles A, Honeyman M, Maguire D, Das P. Understanding Pressures in General Practice. In Causes of pressure: patient factors. London: King's Fund; may 2016. p. 21-22

14. Andersson SO, Mattsson B. Length of consultations in general practice in Sweden: views of doctors and patients. Fam Pract. 1989;6(2):130-4. https://doi.org/10.1093/fampra/6.2.130

15. Kabeya Y, Uchida J, Toyoda M, et al. Factors affecting consultation length in a Japanese diabetes practice. Diabetes Res Clin Pract. 2017;126:54-9. https://doi.org/10.1016/j.diabres.2016.12.020

16. Lemon TI, Smith RH. Consultation Content not Consultation Length Improves Patient Satisfaction. J Family Med Prim Care. 2014;3(4):333-9. https://doi.org/10.4103/2249-4863.148102

17. Nathan TA, Cohen AD, Vinker S. A new marker of primary care utilization - annual accumulated duration of time of visits. Isr J Health Policy Res. 2017 10;6(1):35.

https://doi.org/10.1186/s13584-017-0159-y

18. Brouns SHA, Stassen PM, Lambooij SLE, et al. Organisational Factors Induce Prolonged Emergency Department Length of Stay in Elderly Patients--A Retrospective Cohort Study. PLoS ONE. 2015;10(8):e0135066.

https://doi.org/10.1371/journal.pone.0135066

19. Parker BT, Marco C. Emergency department length of stay: accuracy of patient estimates. West J Emerg Med. 2014;15(2):170-5.

https://doi.org/10.5811/westjem.2013.9.15816

20. Hutton C, Gunn J. Do longer consultations improve the management of psychological problems in general practice? A systematic literature review. BMC Health Serv Res. 2007;7:71 https://doi.org/10.1186/1472-6963-7-71

21. Jin G, Zhao Y, Chen C, Wang W, Du J, Lu X et al. The length and content of general practice consultation in two urban districts of Beijing: a preliminary observation study. PLoS ONE. 2015;10(8):e0135121.

https://doi.org/10.1371/journal.pone.0135121

22. Orton PK, Pereira Gray D. Factors influencing consultation length in general/family practice. Fam Pract. 2016;33(5):529-34. https://doi.org/10.1093/fampra/cmw056 


\title{
Dužina konsultacije bolesnika u ambulanti Hitne medicinske pomoći u Beogradu
}

\author{
Slavoljub R. Živanovići ${ }^{1}$ Miloranka Đ. Petrov-Kiurski² \\ ${ }^{1}$ Gradski zavod za hitnu medicinsku pomoć, Beograd, Srbija \\ ${ }^{2}$ Republički fond zdravstvenog osiguranja, Zrenjanin, Srbija
}

\section{S AŽETAK}

Cilj rada bio je ispitati dužinu konsultacija bolesnika u ambulanti Hitne medicinske pomoći u Beogradu i utvrditi vezu sa bolesnikovim godinama, polom, postavljenom dijagnozom i propisanim tretmanom (terapijom ili slanjem $u$ drugu zdravstvenu ustanovu).

Analizirana je elektronska baza podataka o dužini konsultacija bolesnika u ambulanti Hitne pomoći u Beogradu. Kod bolesnika koji se upućuju u drugu zdravstvenu ustanovu, čekanje na transfer ulazilo je u vreme konsultacije. U statističkoj obradi, korišćen je programski paket SPSS 11,0 za Windows. Statistička značajnost definisana je za nivo $\mathrm{p}<0,05$.

Prosečno vreme konsultacija iznosilo je 21,07 minuta $\pm 13,44$ minuta. Najčešće, konsultacije su trajale od 10 do 20 minuta. Konsultacije su bile duže ako je bolesnik bila osoba ženskog pola (21,68 minuta), ako je starija osoba od 65 godina (24,65 minuta), kada bolesnik ima više dijagnoza (26,1 minut i 27,28 minuta), kao i kada je $u$ cilju zbrinjavanja ordinirana terapija $u$ ambulanti (25,72 minuta) ili kada je bolesnik upućen $u$ drugu zdravstvenu ustanovu višeg ranga. Razlike su imale izražen statistički značaj $(p<0,01)$. U pogledu dijagnoze, konsultacije su trajale najduže (u proseku 30,88 minuta) kod bolesnika sa dijagnozom zaraznih bolesti (u proseku 30,88 minuta), a potom bolesti sistema krvotoka ( 27,86 minuta) i bolesti sistema za disanje (21,56 minuta). Razlike su imale izražen statistički značaj $(p<0,01)$.

Bolesnikove godine, pol, dijagnoza bolesti i terapijski proces utiču na dužinu konsultacije. Zavisno od dijagnoze, konsultacije traju duže kod bolesnika sa infektivnim, kardiovaskularnim i respiratornim bolestima.

Ključne reči: dužina konsultacija, hitna medicinska pomoć, primarna zdravstvena zaštita 